\title{
Displacement of Tomato Yellow Leaf Curl Virus (TYLCV)-Sr by TYLCV-Is in Tomato Epidemics in Spain
}

\author{
S. Sánchez-Campos, J. Navas-Castillo, R. Camero, C. Soria, J. A. Díaz, and E. Moriones
}

Estación Experimental "La Mayora," Consejo Superior de Investigaciones Científicas, 29750 Algarrobo-Costa, Málaga, Spain. Accepted for publication 23 July 1999.

\begin{abstract}
Sánchez-Campos, S., Navas-Castillo, J., Camero, R., Soria, C., Díaz, J. A., and Moriones, E. 1999. Displacement of tomato yellow leaf curl virus (TYLCV)-Sr by TYLCV-Is in tomato epidemics in Spain. Phytopathology 89:1038-1043.

A progressive displacement of tomato yellow leaf curl virus (TYLCV)-Sr by TYLCV-Is was observed in tomato epidemics in southern Spain based on incidence data of both virus species obtained during surveys conducted

in weeds and alternate crops, have been analyzed. No selective advantage is observed for TYLCV-Sr or TYLCV-Is in tomato plants either infected via Agrobacterium tumefaciens or via B. tabaci. However, TYLCV-Is is more efficiently vectored by local biotypes of $B$. tabaci; and common bean, a bridge crop between tomato crops, is a host for TYLCV-Is but not TYLCV-Sr. Therefore, common bean acts as a reservoir for TYLCV-Is. These two factors are probably responsible for the displacement of TYLCV-Sr by TYLCVIs as the causative agent of epidemics in tomato in southern Spain.
\end{abstract} between 1996 and 1998. Ecological factors that might be involved in such a displacement, such as competition of TYLCV-Sr and TYLCV-Is in tomato, transmission by local biotypes (B and Q) of Bemisia tabaci, and presence
Additional keywords: epidemiology, host range, Lycopersicon esculentum, Phaseolus vulgaris, virus displacement.
Tomato yellow leaf curl virus (TYLCV) comprises a group of geminivirus species of the genus Begomovirus in the family Geminiviridae (6) that causes severe damage to tomato (Lycopersicon esculentum Mill.) crops in many tropical and subtropical regions worldwide $(2,11)$. TYLCV was first reported in Spain in 1992 as the causal agent of severe epidemic outbreaks of the yellow leaf curl disease in tomato crops (23). Since then, TYLCV has spread to all of the main vegetable-producing regions of southern and southeastern Spain, where it has become the limiting factor for tomato production during the summer and fall, causing up to $100 \%$ yield loss (E. Moriones, unpublished data). Isolates of the TYLCV-Sr species were found to be involved in TYLCV epidemics in Spain $(26,28)$. Recently, in these same regions, abnormally severe TYLCV outbreaks associated with another TYLCV species, TYLCV-Is (24), have occurred. These were subsequently shown to be widespread in tomato-growing areas in southern and southeastern Spain. TYLCV-Is was also found to be the causal agent of a novel disease of common bean (Phaseolus vulgaris L.), bean leaf crumple disease, which has caused extensive damage in fresh-market crops from the southern regions since September 1997 (25). TYLCV-Sr and TYLCV-Is are virus species taxonomically close to each other (27). Isolates of each species from Spain (GenBank accession numbers Z25751 and AF071228, respectively) showed a nucleotide sequence similarity between their genomes of about $78 \%$. This is the first time that the coexistence of TYLCV-Sr and TYLCV-Is in the same area has been reported, and this situation offers a good natural scenario for studies on competition of viruses that share similar ecological niches (host range, cell and tissue tropism, vector tropism, etc.).

TYLCV isolates are transmitted by the whitefly Bemisia tabaci (Gennadius) (Sternorrhyncha: Aleyrodidae) in a persistent circulative manner $(8,9,18,22)$. Emergence of TYLCV outbreaks in new areas has been related to the spread of their vector (3). Within $B$.

Corresponding author: E. Moriones; E-mail address: moriones@eelm.csic.es

Publication no. P-1999-0907-01R

(C) 1999 The American Phytopathological Society tabaci, isozyme analysis $(10,30)$ and comparison of random amplified polymorphic DNA-polymerase chain reaction (RAPD-PCR) profiles (14) has led to the recognition of distinct biotypes. Recent studies have shown that Spanish B. tabaci populations are composed of at least two genetic types: one that corresponds to populations of the worldwide-distributed biotype B (3) and another that seems to be specific for Spain and Portugal, biotype Q (16). No information is available on whether a differential relationship exists between B. tabaci biotypes and TYLCV species present in Spain.

We report here the progressive displacement of TYLCV-Sr by TYLCV-Is in epidemics on tomato in the Málaga region (southern Spain). A study has been undertaken in order to understand the ecological basis of such a displacement. We conclude that two factors are probably responsible for the displacement. One is that TYLCVIs is more efficiently vectored by local biotypes of $B$. tabaci. The second is that common bean, a bridge crop between tomato crops, is a host for TYLCV-Is but not TYLCV-Sr, suggesting that common bean acts as a reservoir for TYLCV-Is.

\section{MATERIALS AND METHODS}

Field surveys. The main tomato-growing area in the province of Málaga (southern Spain) is located in a narrow region of approximately $50 \mathrm{~km}$ along the Mediterranean coast, where staked tomatoes for fresh markets are produced. In this region, a survey was conducted during the 1996, 1997, and 1998 growing seasons at four sites $15 \mathrm{~km}$ apart representing the major tomato-growing areas. At each site, several randomly selected field-grown commercial tomato crops transplanted during August were sampled every year at the end of October, and the incidence of TYLCV-Sr and TYLCV-Is was analyzed. In each crop, approximately 50 tomato plants were collected by systematic sampling following a W-shaped itinerary (17). Tomato cultivars present were susceptible to TYLCV$\mathrm{Sr}$ and TYLCV-Is based on the severity of the symptoms exhibited in field-infected plants.

The presence of TYLCV-Sr, TYLCV-Is, or both in weed species associated with tomato crops as well as in common bean crops was also analyzed. Surveys were conducted during fall 1997 and 1998 
near the sites where tomato crops were surveyed. Leaf samples were collected from weeds found in great abundance in or around tomato fields and from common bean crops that coexisted with or followed tomato crops in the rotations. Samples were randomly collected except when indicated.

Samples consisted of one terminal leaf per plant that was stored at $4{ }^{\circ} \mathrm{C}$ until analyzed. Each sample was analyzed for TYLCV-Sr or TYLCV-Is infection by hybridization of a petiole cross section printed on positively charged nylon (nylon ${ }^{+}$) membranes (Boehringer Mannheim GmbH, Mannheim, Germany), hereafter referred to as tissue blotting. Healthy tomato and common bean plants were used as negative controls; tomato plants experimentally infected with either TYLCV-Sr or TYLCV-Is served as positive controls. For hybridization, digoxigenin (DIG)-labeled DNA probes specific to each virus were prepared using the DIG-labeling and detection kit (Boehringer Mannheim GmbH) as described by Navas-Castillo et al. (25). Hybridization was carried out at high stringency conditions (washing steps at $65^{\circ} \mathrm{C}$ in $0.1 \times \mathrm{SSC}[15 \mathrm{mM} \mathrm{NaCl}$ and $1.5 \mathrm{mM}$ sodium citrate] and $0.1 \%$ sodium dodecyl sulfate) following standard protocols. Positive results in weed samples were confirmed by identification of viral DNA forms in Southern blots of total nucleic acids performed according to the procedure described by Noris et al. (26).

Origins and maintenance of virus cultures and whitefly colonies. The construction of infectious clones for the TYLCV-Sr and TYLCV-Is from Spain has already been described $(25,26)$. Nonviruliferous $B$. tabaci colonies of the biotypes B or Q established from field individuals collected in the Málaga province were reared on melon plants (Cucumis melo L. ANC42) grown in insect-proof cages maintained in an insect-proof greenhouse at approximately $25^{\circ} \mathrm{C}$ day and $20^{\circ} \mathrm{C}$ night with a 16 -h photoperiod. B. tabaci biotyping was done by RAPD-PCR analysis as reported (16).

Competition of TYLCV-Sr and TYLCV-Is in tomato plants. Tomato plants (L. esculentum cv. Moneymaker) were infected with TYLCV-Sr, TYLCV-Is, or both at the four-leaf growth stage by Agrobacterium-mediated inoculation as described elsewhere (26). For mixed inoculations, liquid cultures of A. tumefaciens containing either the TYLCV-Sr or TYLCV-Is infectious clones were adjusted to an optical density of 1.0 at $600 \mathrm{~nm}$ and mixed in equal volumes. Also, mixed infection of tomato plants by $B$. tabaci biotype $\mathrm{Q}$ inoculation was performed following the same procedure described below, except that 10 individuals per test plant were used for transmission. After infection, plants were maintained in a growth chamber at $25^{\circ} \mathrm{C}$ day and $20^{\circ} \mathrm{C}$ night, $70 \%$ relative humidity (RH), and a 16-h photoperiod until analyzed. At different times postinoculation (PI) (from 30 to 120 days PI), TYLCV-Sr and TYLCVIs DNA levels were estimated in the young tissues of each test plant as described below.

Estimation of TYLCV-Sr and TYLCV-Is DNA levels in infected tomato plants. Viral DNA levels were estimated in the youngest leaf of test plants. Total nucleic acid extracts were prepared as reported (26) and series of dilutions applied to nylon ${ }^{+}$membranes for dot blot hybridization analysis. Assessment of viral DNA content in each tested sample was done by densitometry measure of hybridization signals obtained in autoradiographs of dot blots hybridized with TYLCV-Sr- or TYLCV-Is-specific probes (described above). Hybridization and specific activity quantification controls of each probe were equal amounts of DNA fragments representative of the intergenic region of TYLCV-Sr or TYLCV-Is. The intergenic region fragments were obtained by PCR amplification using isolates and primers reported elsewhere (25). Densitometry measures were expressed in pixels measured by the image analysis system (EDAS 120 Image Analysis System; Eastman Kodak, Rochester, NY). In mixed infections, standardization of the amount of each virus species for comparison within each tested sample was obtained by calculating the ratio of viral DNA pixels to the pixels measured for the specific activity quantification control of each virus species probe. For comparison of values obtained from different plants or from different extracts of the same plant, a cauliflower ribosomal DNA-specific probe prepared by random priming to a clone of a fragment of cauliflower $18 \mathrm{~S}$ ribosomal RNA gene provided by E. R. Rodríguez-Cerezo (CNB-CSIC, Madrid, Spain) was used to detect plant ribosomal DNA, which served as an internal standard for total plant genomic DNA. The amount of each virus species in the test sample was then standardized by calculating the ratio of viral DNA pixels to the pixels of the probespecific activity quantification control and plant ribosomal DNA pixels. In every case, the densitometry results used were those from a dilution that fell within the linear range of the relationship between dilution and densitometry measure.

Acquisition and transmission of TYLCV by B. tabaci. Acquisition was done on a tomato ( $L$. esculentum cv. Moneymaker) plant infected with equal amounts of both viral species (analyzed as described above) to avoid a bias on transmission results due to differential viral titer in acquisition sources or to differential physiological conditions of acquisition sources that could affect vector behavior if different plants are used for acquisition of each viral species. Young leaves (leaf number 2 from the apex) from mixedinfected plants were selected for virus acquisition. Adult female whiteflies were caged with selected leaves in groups of 80 using clip-on cages and were given a 24-h acquisition access period (AAP). $B$. tabaci females were used for transmission experiments because they are more numerous and live longer than males in $B$. tabaci populations $(7,29)$ and are reported to be more efficient transmitters of TYLCV $(8,9)$. After the AAP, insects were collected and caged in groups of two on leaf number 2 from the apex of each tomato test plant (50 plants per experiment) at the four-leaf growth stage for a 24-h inoculation access period (IAP). Transmission experiments were repeated four times with each $B$. tabaci biotype. Acquisition and inoculation were performed in a growth chamber at $25^{\circ} \mathrm{C}$ day and $20^{\circ} \mathrm{C}$ night, $70 \% \mathrm{RH}$, and a 16-h photoperiod. Insect activity was registered at the end of the IAP, and only data from those plants in which the two B. tabaci individuals survived to this period were considered for further analysis. After the IAP, insects were individually collected and squashed onto nylon ${ }^{+}$membranes. Whitefly blots were probed for TYLCV-Sr, stripped, and then probed for TYLCV-Is following the same procedure used for tissue blot hybridization. The test plants were then sprayed with imidacloprid (Confidor; Bayer A.G., Leverkusen, Germany) and kept in the growth chamber until analyzed. Preliminary studies indicated that, only 4 weeks after the IAP, all of the infected plants were detected by tissue blotting. Therefore, test plants were analyzed 4 weeks after the IAP for TYLCV-Sr or TYLCV-Is infection by tissue blotting using the youngest leaf for analysis. Controls were tomato plants (10 plants per experiment) exposed in the same conditions to whiteflies from the nonviruliferous colonies. The transmission data were used to estimate the probability of disease transmission by a single vector $(p)$, using the formula of Gibbs and Gower (15), $p=1-(1-R / N)^{1 / i}$, in which $p$ is the probability of a single whitefly transmitting, $R$ is the number of plants infected, $N$ is the number of plants exposed to infection, and $i$ is the number of insects used per plant, assuming that the vectors act independently.

Statistical analyses. The effect of B. tabaci biotype and TYLCV species on vectoring efficiency was analyzed by means of virus $X$ biotype factorial analyses of variance of data after arcsinsqrt transformation. Means were separated by using the least significant difference at $P=0.05$ (SAS system; SAS Institute, Cary, NC).

\section{RESULTS}

Displacement of TYLCV-Sr by TYLCV-Is in tomato epidemics. Results of the analysis of tomato samples collected during the 1996, 1997, and 1998 growing seasons in a 50-km transect of the main tomato-growing areas of the Málaga region (southern Spain) are summarized in Table 1. The data obtained show the relevance of TYLCV infections in field-grown tomato crops in this area, 
in which incidences up to $100 \%$ were frequent in the last 6 years, especially during 1998. The data showed a shift in the incidence of TYLCV-Is from a minor presence detected during the 1996 epidemics to the predominant strain in every site sampled during the 1998 outbreak. Therefore, data suggested that a progressive displacement of TYLCV-Sr by TYLCV-Is is occurring in tomato crops in this area of southern Spain.

TYLCV-Sr and TYLCV-Is are equally maintained in tomato plants. Competition experiments were performed to determine if the displacement between the TYLCV species observed in epidemics in tomato was due to a differential fitness of both viral species in this host. The results indicated that no evident displacement of any virus species occurred 30 days PI in plants that were coinfected with both viruses via A. tumefaciens. Measurement of the amount of TYLCV-Sr and TYLCV-Is revealed a ratio ( $\mathrm{Sr} / \mathrm{Is})$ close to 1 (mean \pm standard deviation, $1.07 \pm 0.16 ; n=11$ ). Indeed, this ratio was maintained in plants that were analyzed at 60 and 120 days PI (ratio Sr/Is, $0.96 \pm 0.06$ and $1.15 \pm 0.16$, respectively; $n=3$ ). The same results were obtained at 30 days PI for tomato plants that were mixed-infected with TYLCV-Sr and TYLCV-Is by $B$. tabaci inoculation (ratio Sr/Is, $1.06 \pm 0.02 ; n=3$ ). Indeed, the amount of each virus species in mixed-infected tomato plants was not sig- nificantly different from that present in singly infected plants when analyzed at equivalent days PI (data not shown). Therefore, our results indicated that neither virus species out-competed the other in tomato in our experimental conditions, even after 120 days of coinfection, which was the normal duration of a tomato crop in the area considered. This suggests that both TYLCV-Sr and TYLCVIs have similar fitnesses in this plant host.

TYLCV-Is is more efficiently transmitted by $B$. tabaci than is TYLCV-Sr. Natural transmission of TYLCV occurs through their vector, B. tabaci. Transmission experiments were performed to determine if differential transmission of TYLCV-Sr and TYLCVIs exists for $B$. tabaci biotypes B or Q, which could contribute to the observed displacement of TYLCV-Sr by TYLCV-Is (Table 2). Differences were observed between biotypes B and Q in their ability to transmit the TYLCV species. Biotype Q appeared to transmit both viral species more efficiently, infecting significantly higher percentages of test plants during transmission experiments than did biotype $\mathrm{B}$. In addition, differences were observed in the ability of biotypes B and Q to transmit TYLCV-Sr and TYLCV-Is, with TYLCV-Is transmitted more efficiently by both biotypes, at significant levels $(P=0.05)$ for biotype B (Table 2$)$. Transmission results were converted using the formula of Gibbs and Gower (15)

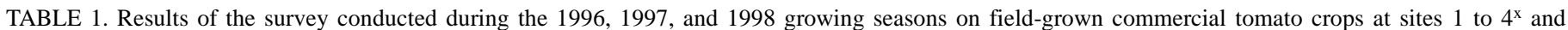
analysis of the samples for infection of tomato yellow leaf curl virus (TYLCV)-Sr, TYLCV-Is, or both

\begin{tabular}{|c|c|c|c|c|c|c|c|}
\hline \multirow[b]{2}{*}{ Site } & \multirow[b]{2}{*}{ Year } & \multirow[b]{2}{*}{ Fields sampled } & \multirow[b]{2}{*}{ Samples collected } & \multicolumn{3}{|c|}{ No. of positive samples $(\%)^{\mathrm{y}}$} & \multirow[b]{2}{*}{ No. of TYLCV-infected samples $(\%)^{\mathrm{z}}$} \\
\hline & & & & $\mathrm{Sr}$ & Is & $\mathrm{Sr}+\mathrm{Is}$ & \\
\hline \multirow[t]{3}{*}{1} & 1996 & 5 & 250 & $129(51.6)$ & $9(3.6)$ & $20(8.0)$ & $158(63.2)$ \\
\hline & 1997 & 5 & 260 & $54(20.8)$ & $93(35.8)$ & $36(13.9)$ & $183(70.4)$ \\
\hline & 1998 & 5 & 249 & $6(2.4)$ & $180(72.3)$ & $57(22.9)$ & $243(97.6)$ \\
\hline \multirow[t]{3}{*}{2} & 1996 & 5 & 250 & $100(40.0)$ & $26(10.4)$ & $65(26.0)$ & $191(76.4)$ \\
\hline & 1997 & 5 & 277 & $44(15.9)$ & 105 (37.9) & $102(36.8)$ & $251(90.6)$ \\
\hline & 1998 & 2 & 104 & $1(0.9)$ & $84(80.8)$ & $17(16.4)$ & $102(98.1)$ \\
\hline \multirow[t]{3}{*}{3} & 1996 & 5 & 250 & $104(41.6)$ & $19(7.6)$ & $89(35.6)$ & $212(84.8)$ \\
\hline & 1997 & 1 & 18 & $1(5.6)$ & $1(5.6)$ & $16(88.9)$ & $18(100)$ \\
\hline & 1998 & 2 & 100 & $3(3.0)$ & $74(74.0)$ & $13(13.0)$ & $90(90.0)$ \\
\hline \multirow[t]{3}{*}{4} & 1996 & 5 & 250 & $63(25.2)$ & $17(6.8)$ & $45(18.0)$ & $125(50.0)$ \\
\hline & 1997 & 1 & 50 & $4(8.0)$ & $32(64.0)$ & $4(8.0)$ & $40(80.0)$ \\
\hline & 1998 & 2 & 101 & $0(0)$ & $65(64.3)$ & $36(35.7)$ & $101(100)$ \\
\hline
\end{tabular}

x Sites 1 to 4 are representative of the different tomato-growing areas of the Málaga region (southern Spain).

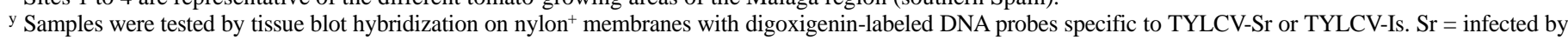

TYLCV-Sr, Is = infected by TYLCV-Is, and Sr + Is = infected by TYLCV-Sr and TYLCV-Is. Percentages were calculated over total collected samples.

z Total number of samples infected by TYLCV-Sr, TYLCV-Is, or TYLCV-Sr + TYLCV-Is. Percentages were calculated over total collected samples.

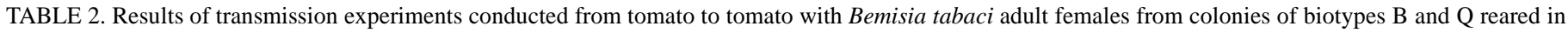
the laboratory from field individuals collected in the Málaga province

\begin{tabular}{|c|c|c|c|c|c|}
\hline \multirow[b]{2}{*}{ B. tabaci biotype } & \multirow[b]{2}{*}{ No. of replicates ${ }^{w}$} & \multicolumn{2}{|c|}{ Average percent plants infected ${ }^{\mathrm{x}, \mathrm{y}}$} & \multicolumn{2}{|c|}{ Average probability of insect transmission ${ }^{\mathrm{y}, \mathrm{z}}$} \\
\hline & & TYLCV-Sr & TYLCV-Is & TYLCV-Sr & TYLCV-Is \\
\hline B & 4 & $11.8 \mathrm{c}$ & $33.7 \mathrm{~b}$ & $0.06 \mathrm{c}$ & $0.19 \mathrm{~b}$ \\
\hline $\mathrm{Q}$ & 4 & $40.1 \mathrm{ab}$ & $50.0 \mathrm{a}$ & $0.23 \mathrm{ab}$ & $0.29 \mathrm{a}$ \\
\hline
\end{tabular}

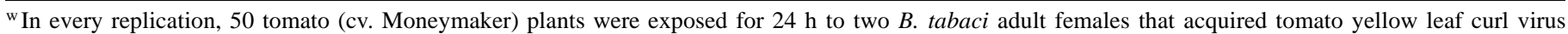
(TYLCV) from a tomato (cv. Moneymaker) plant mixed-infected with TYLCV-Sr and TYLCV-Is. After discarding plants in which the two B. tabaci individuals did not survive the inoculation access period, replicates for biotypes B and Q were based on experiments with 46, 45, 45, and 43 plants, and 45, 39, 36, and 49 plants, respectively.

x Plants were tested by tissue blot hybridization on nylon ${ }^{+}$membranes with digoxigenin-labeled DNA probes specific to TYLCV-Sr or TYLCV-Is.

y Values with the same letters did not differ significantly; $P \leq 0.05$, least significant difference (SAS system).

${ }^{\mathrm{z}}$ Probability was calculated in each experiment based on the formula $p=1-(1-R / N)^{1 / i}(15)$.

TABLE 3. Results of the analysis of tomato yellow leaf curl virus (TYLCV)-Sr or TYLCV-Is infections in single Bemisia tabaci individuals of biotype B or Q involved in the transmission experiments ${ }^{\mathrm{z}}$

\begin{tabular}{lccccc}
\hline & & \multicolumn{3}{c}{ No. of positive reactions (\%) } & \multirow{2}{*}{ No. of negative reactions (\%) } \\
\cline { 3 - 5 } B. tabaci biotype & Total single whiteflies tested & $\mathrm{Sr}$ & $\mathrm{Is}$ & $\mathrm{Sr}+\mathrm{Is}$ & $273(78.9)$ \\
$\mathrm{B}$ & 346 & $24(6.9)$ & $10(2.9)$ & $240(81.8)$ & $39(11.3)$ \\
Q & 296 & $17(5.7)$ & $8(2.7)$ & $31(10.5)$ &
\end{tabular}

${ }^{z}$ Each whitefly individual was tested for both TYLCV-Sr or TYLCV-Is infection by squash blot hybridization on nylon ${ }^{+}$membranes with digoxigenin-labeled DNA probes specific to TYLCV-Sr or TYLCV-Is. Whitefly blots were probed for one virus, stripped, and then probed for the second virus. Sr $=$ infected by TYLCV-Sr, Is = infected by TYLCV-Is, Sr + Is = infected by TYLCV-Sr and TYLCV-Is. Percentages were calculated over the total number of whiteflies tested. 
to express the probability of a single insect to transmit (Table 2). The probability of a biotype B individual transmitting TYLCV-Sr is 0.06 , which is significantly lower than the probability of a biotype Q individual transmitting the same virus (0.23). Differences were observed for TYLCV-Is as well ( 0.19 versus 0.29 for biotypes B and Q, respectively), although they were smaller. Therefore, differences exist between biotypes B and Q in their ability to transmit TYLCV species, particularly for TYLCV-Sr, and may contribute to the displacement observed.

Observed differences in transmission were not due to differences in the ability of biotype B or Q to acquire TYLCV-Sr or TYLCV-Is from the virus source: each whitefly insect used in transmission experiments was analyzed for both TYLCV-Sr and TYLCV-Is infection, showing that most of them acquired both viruses during AAP (Table 3). The study of virus infection of each pair of whiteflies used for transmission to each test plant showed that, except in a few cases, test plants were exposed to both TYLCV-Sr and TYLCV-Is infection (data not shown). Therefore, differences in the ability of transmission of TYLCV-Sr or TYLCV-Is found for biotypes B and $\mathrm{Q}$ were most likely due to factors other than virus acquisition.

Presence of TYLCV-Sr and TYLCV-Is in alternate hosts. More than 520 weed samples representing 38 species in 20 families were collected and tested for TYLCV-Sr and TYLCV-Is infection during fall 1997 and 1998 (Table 4). Results showed that TYLCV-Sr or TYLCV-Is infections were rare in wild hosts. All samples collected from weeds were negative except for Datura stramonium L. and Solanum nigrum L. samples collected from plants growing within or around heavily infected tomato fields. TYLCV$\mathrm{Sr}$ alone or TYLCV-Sr and TYLCV-Is together were found in $D$. stramonium and only TYLCV-Sr in S. nigrum.

Common bean is a widespread crop in southern Spain (nearly 10,000 ha cultivated) (19) and usually serves as a bridge crop between fall and spring tomatoes. Common bean has been reported as a host of TYLCV (9), and epidemics of bean leaf crumple disease in Spain were associated with infections caused by TYLCV-Is (25). Therefore, samplings of this species were conducted during the current survey to study its possible role as a TYLCV reservoir. The results of the analysis of the samples collected indicated that only TYLCV-Is was found infecting common bean crops (Table 4). Also, experimental infection of common bean (cv. Donna) with TYLCV-Sr or TYLCV-Is by Agrobacterium-mediated inoculation indicated that only TYLCV-Is was able to infect this species (E. Moriones, unpublished data).

\section{DISCUSSION}

TYLCV-Sr has been present since 1992 (23) in southern Spain, causing severe epidemic outbreaks in tomato crops. TYLCV-Is has only recently been reported to infect tomatoes in the same area (24). In this study, a rapid displacement of TYLCV-Sr by TYLCVIs was observed in epidemics occurring in tomato in southern Spain. Knowledge of the reasons underlying the selective advantage of TYLCV-Is in tomato epidemics is essential for prediction of future progression of TYLCV epidemics and, therefore, for correct control strategies to be implemented. In this study, we investigated several aspects of the ecology of these viruses that could be involved in the observed displacement, such as competition between TYLCV$\mathrm{Sr}$ and TYLCV-Is in tomato, relationships with the natural vector B. tabaci, and spread in natural hosts.

No selective advantage has been observed for TYLCV-Sr or TYLCV-Is in tomato plants inoculated via either Agrobacterium or B. tabaci. Even after 120 days of coexistence of both viruses in the same plant, which is the normal duration of a tomato crop, similar amounts of both viruses were present in mixed-infected plants. Therefore, no displacement should be expected in tomato due to competition between the TYLCV species.

The only known mechanism for spread of TYLCV-Sr or TYLCVIs in nature is through their vector, B. tabaci. Therefore, the in-
TABLE 4. Field surveys of tomato yellow leaf curl virus (TYLCV)-Sr and TYLCV-Is in weeds and common bean (Phaseolus vulgaris) crops performed in southern Spain during fall 1997 and 1998

\begin{tabular}{|c|c|c|c|c|}
\hline \multirow[b]{2}{*}{ Host, family, species } & \multirow[b]{2}{*}{ Samples } & \multicolumn{3}{|c|}{ No. of positive samples ${ }^{\mathrm{w}}$} \\
\hline & & $\mathrm{Sr}$ & Is & $\mathrm{Sr}+\mathrm{Is}$ \\
\hline \multicolumn{5}{|l|}{ Weeds } \\
\hline \multicolumn{5}{|l|}{ Aizoaceae } \\
\hline Mesembryanthemun sp. & 3 & 0 & 0 & 0 \\
\hline \multicolumn{5}{|l|}{ Amarantaceae } \\
\hline Amaranthus graecizans L. & 14 & 0 & 0 & 0 \\
\hline Amaranthus viridis L. & 32 & 0 & 0 & 0 \\
\hline Amaranthus sp. & 9 & 0 & 0 & 0 \\
\hline \multicolumn{5}{|l|}{ Asclepiadaceae } \\
\hline Cynanchum acutum L. & 2 & 0 & 0 & 0 \\
\hline \multicolumn{5}{|l|}{ Borraginaceae } \\
\hline Echium creticum $\mathrm{L}$. & 10 & 0 & 0 & 0 \\
\hline \multicolumn{5}{|l|}{ Caprifoliaceae } \\
\hline Lonicera sp. & 4 & 0 & 0 & 0 \\
\hline \multicolumn{5}{|l|}{ Chenopodiaceae } \\
\hline Chenopodium ambrosioides L. & 14 & 0 & 0 & 0 \\
\hline Chenopodium album $\mathrm{L}$. & 18 & 0 & 0 & 0 \\
\hline \multicolumn{5}{|l|}{ Compositae } \\
\hline Bidens aurea (Aiton) Sherff & 16 & 0 & 0 & 0 \\
\hline Bidens pilosa $\mathrm{L}$. & 11 & 0 & 0 & 0 \\
\hline Conyza bonariensis (L.) Cronquist & 13 & 0 & 0 & 0 \\
\hline Conyza sp. & 1 & 0 & 0 & 0 \\
\hline Dittrichia viscosa (L.) Greuter & 20 & 0 & 0 & 0 \\
\hline Heliotropium europaeum L. & 9 & 0 & 0 & 0 \\
\hline Sonchus oleraceus L. & 12 & 0 & 0 & 0 \\
\hline \multicolumn{5}{|l|}{ Convolvulaceae } \\
\hline Convolvulus arvensis L. & 29 & 0 & 0 & 0 \\
\hline Convolvulus betonicifolius Mill. & 14 & 0 & 0 & 0 \\
\hline \multicolumn{5}{|l|}{ Euphorbiaceae } \\
\hline Chamaecysus nutans (Lag.) Small & 8 & 0 & 0 & 0 \\
\hline Euphorbia hirsuta L. & 21 & 0 & 0 & 0 \\
\hline Ricinus communis L. & 14 & 0 & 0 & 0 \\
\hline \multicolumn{5}{|l|}{ Geraniaceae } \\
\hline Geranium sp. & 1 & 0 & 0 & 0 \\
\hline \multicolumn{5}{|l|}{ Labiatae } \\
\hline Mentha suaveolens Ehrh. & 10 & 0 & 0 & 0 \\
\hline Mentha sp. & 6 & 0 & 0 & 0 \\
\hline Malvaceae & & & & \\
\hline Althaea sp & 2 & 0 & 0 & 0 \\
\hline Hibiscus rosa-sinensis L. & 2 & 0 & 0 & 0 \\
\hline Lavatera sp. & 13 & 0 & 0 & 0 \\
\hline Malva sp. & 14 & 0 & 0 & 0 \\
\hline Nictaginaceae & & & & \\
\hline Mirabilis jalapa L. & 9 & 0 & 0 & 0 \\
\hline Oxalidaceae & & & & \\
\hline Oxalis pes-caprae $\mathrm{L}$. & 6 & 0 & 0 & 0 \\
\hline Poligonaceae & & & & \\
\hline Emex spinosa (L.) Campd. & 6 & 0 & 0 & 0 \\
\hline Portulacaceae & & & & \\
\hline Portulaca oleracea $\mathrm{L}$. & 11 & 0 & 0 & 0 \\
\hline Rubiaceae & & & & \\
\hline Rubia peregrina $\mathrm{L}$. & 6 & 0 & 0 & 0 \\
\hline Solanaceae & & & & \\
\hline Datura stramonium L. & 23 & 0 & 9 & 4 \\
\hline Nicotiana glauca R. C. Graham & 38 & 0 & 0 & 0 \\
\hline Solanum nigrum L.y & 59 & 35 & 0 & 0 \\
\hline Urticaceae & & & & \\
\hline Parietaria judaica L. & 31 & 0 & 0 & 0 \\
\hline Verbenaceae & & & & \\
\hline Verbena officinalis L. & 10 & 0 & 0 & 0 \\
\hline Common bean ${ }^{\mathrm{z}}$ & & & & \\
\hline Papilionaceae & & & & \\
\hline Phaseolus vulgaris L. & 91 & 0 & 71 & 0 \\
\hline
\end{tabular}

${ }^{\mathrm{w}}$ Except when indicated, plants were tested by tissue blot hybridization on nylon ${ }^{+}$ membranes with digoxigenin-labeled DNA probes specific to TYLCV-Sr or TYLCV-Is. Sr = infected by TYLCV-Sr, Is = infected by TYLCV-Is, and Sr + Is = infected by TYLCV-Sr and TYLCV-Is.

${ }^{\mathrm{x}}$ Detection was based on single-strand conformation polymorphism analysis as described by Navas-Castillo et al. (25) because nonspecific signal was obtained in hybridization analysis.

${ }^{y}$ Initially, few samples collected from two sites adjacent to tomato fields heavily infected by tomato yellow leaf curl virus tested positive. Additional samples were then collected from these two sites.

${ }^{\mathrm{z}}$ High incidences of bean leaf crumple symptoms were observed in southern Spain common bean crops during 1997 and 1998. Samples were collected from different sites covering the growing area in the province of Málaga. 
teraction between TYLCV and B. tabaci was analyzed. Two different biotypes of $B$. tabaci (biotypes B and Q) have been reported to exist in southern Spain $(1,16)$. In this study, we have shown a differential interaction between the TYLCV species and the $B$. tabaci biotypes. In fact, biotype Q transmitted both TYLCV species more efficiently than did biotype B. In addition, TYLCV-Sr was less efficiently transmitted by both biotypes, at significant levels $(P=0.05)$ for biotype B. Biotype B showed, on average, a transmission probability of 0.06 per insect for TYLCV-Sr when using two insects per tested plant, while under the same conditions, a value of 0.19 was obtained for TYLCV-Is. Therefore, TYLCV-Is appears to be better adapted to transmission by $B$. tabaci and a preferential dispersion of this virus species would be expected during epidemics. No information is available in Spain about the relative predominance of biotypes B and Q in B. tabaci populations throughout the year. Our observations from healthy biotype B and $\mathrm{Q}$ colonies maintained in a greenhouse, however, indicated that biotype B populations developed much faster than biotype Q populations during the hot period (July to September). This would determine a predominance of biotype B during hot periods in the field when the major spread of TYLCV occurs and, therefore, result in a more efficient dispersion of TYLCV-Is during epidemics. This might allow TYLCV-Is to persist more efficiently than TYLCV-Sr in tomato epidemics. Therefore, this is an aspect that should be more carefully studied by systematic sampling of B. tabaci populations throughout the year. Changes in virus composition in a certain region due to a shift in vector populations have been well documented. This is the case of lettuce infectious yellows virus (LIYV) in California and Arizona, which almost disappeared as an economic problem due to the displacement of B. tabaci biotype A by biotype B, a much poorer vector of LIYV (12). A similar situation occurred on melon in Spain for beet pseudoyellows virus, which was virtually replaced by the cucurbit yellows stunting disorder virus due to the displacement of Trialeurodes vaporariorum by B. tabaci (5).

Transmission differences found between $B$. tabaci biotypes were not related to acquisition, because similar acquisition efficiencies were deduced for both biotypes B and Q from our experiments. However, as suggested by McGrath and Harrison (21), the assay used for detection of TYLCV in the vector only informs about the presence of viral DNA within B. tabaci individuals, irrespective of whether it is assembled or not into viral particles, and it does not take into account possible differences in the specific activity of particles in virus sources. This is an aspect that should be further studied.

Along with competition and vector transmission, maintenance of viruses between epidemics in alternate hosts present in the area provides a means to survive through the seasonal cycle (20), and could determine their relative predominance. Analysis of the presence of TYLCV species in weeds showed that TYLCV-Sr or TYLCVIs are rarely found in wild plants that grow in or around tomato fields. Two species, D. stramonium and S. nigrum, appeared as possible virus reservoirs for TYLCV-Is and TYLCV-Sr and, therefore, may contribute to maintenance of both virus species. Indeed, these weed species were reported to be good sources for $B$. tabaci acquisition of TYLCV and transmission to tomato $(4,9)$. More frequent were infections of TYLCV-Is in common bean. Severe epidemics of TYLCV-Is on common bean were reported in southern Spain in 1997 (25), and relatively frequent infections were detected in the current survey. Infections in this species are especially important for virus maintenance through the seasonal cycle, because common bean is commonly used as a bridge crop between fall and spring tomato crops in the region considered. Therefore, the species combination used in crop rotations in the Málaga region may allow TYLCV-Is to survive more efficiently than TYLCV-Sr in successive tomato crops grown in the same locality throughout the year.

In conclusion, we have described the displacement of TYLCV-Sr with TYLCV-Is over a 3-year period in tomatoes grown in southern Spain and provided arguments for the reasons behind this displace- ment: TYLCV-Is has a reservoir in common bean and is more efficiently transmitted by the whitefly vector. In these conditions, displacement of TYLCV-Sr by TYLCV-Is might be expected, although more accurate studies on biotype predominance in $B$. tabaci populations in southern Spain should be done for a more comprehensive understanding of TYLCV epidemics in tomato.

Tomato production in southern Spain accounts for $30 \%$ of the total national production (19). The emergence of TYLCV epidemics has become a major constraint to tomato production in this region. In this study, useful information has been obtained on the ecology of TYLCV-Sr and TYLCV-Is in southern Spain and the basis of the displacement of TYLCV-Sr by TYLCV-Is. This information could help in understanding the dynamics of TYLCV epidemics on tomato and contribute to the eventual control of these viruses. The knowledge of the existence of a displacement between TYLCV species can be crucial for the management of infections in tomato, because development of resistant cultivars is the best option for their control and differences in the behavior of breeding lines against different TYLCV species are known to exist (13).

\section{ACKNOWLEDGMENTS}

This work was financed by projects AGF96-0421 and AGF98-0439 of the Comisión Interministerial de Ciencia y Tecnología, Spain, and by Caja Rural de Málaga, Spain. S. Sánchez-Campos is the recipient of a predoctoral fellowship from the Ministerio de Educación y Cultura, Spain. We thank J. L. Cenis and F. Beitia for vector biotyping, R. Fernández for his help in the statistical analyses, E. R. RodríguezCerezo, for providing the clone of a fragment of cauliflower $18 \mathrm{~S}$ ribosomal RNA gene, J. Toro for weed species identification, and M. A. Aranda and G. C. Wisler for critical review of the manuscript.

\section{LITERATURE CITED}

1. Banks, G. K., Green, R. L., Cerezo, E. R., Louro, D., and Markham, P. 1998. Use of RAPD-PCR to characterize whitefly species in the Iberian peninsula. Page L-18 in: Proc. Int. Workshop Bemisia Geminiviruses, 2nd. Organizing Committee, San Juan, Puerto Rico.

2. Bedford, I. D., Briddon, R. W., Brown, J. K., Jones, P., Alkaff, N., and Markham, P. G. 1994. Differentiation of three whitefly-transmitted geminiviruses from the Republic of Yemen. Eur. J. Plant Pathol. 100:243-257.

3. Bedford, I. D., Briddon, R. W., Brown, J. K., Rosell, R. C., and Markham, P. G. 1994. Geminivirus transmission and biological characterization of Bemisia tabaci (Gennadius) biotypes from different geographic regions. Ann. Appl. Biol. 125:311-325.

4. Bedford, I. D., Kelly, A., Banks, G. K., Briddon, R. W., Cenis, J. L., and Markham, P. G. 1998. Solanum nigrum: An indigenous weed reservoir for tomato yellow leaf curl geminivirus in southern Spain. Eur. J. Plant Pathol. 104:221-222.

5. Berdiales, B., Bernal, J. J., Sáez, E., Woudt, B., Beitia, F., and RodríguezCerezo, E. 1999. Occurrence of cucurbit yellow stunting disorder virus (CYSDV) and beet pseudo-yellows virus in cucurbit crops in Spain and transmission of CYSDV by two biotypes of Bemisia tabaci. Eur. J. Plant Pathol. 105:211-215.

6. Briddon, R. W., and Markham, P. G. 1995. Family Geminiviridae. Pages 158-165 in: Virus Taxonomy: Classification and Nomenclature of Viruses. Sixth Report of the International Committee on Taxonomy of Viruses. F. A. Murphy, C. M. Fauquet, D. H. L. Bishop, S. A. Ghabrial, A. W. Jarvis, G. P. Martelli, M. A. Mayo, and M. D. Summers, eds. Springer-Verlag, New York.

7. Butler, Jr., G. D., Henneberry, T. J., and Hutchison, W. D. 1986. Biology, sampling and population dynamics of Bemisia tabaci. Pages 167-195 in: Agricultural Zoology Reviews, Vol. 1. G. E. Russell, ed. Intercept Ltd., Andover, MA.

8. Caciagli, P., Bosco, D., and Al-Bitar, L. 1995. Relationships of the Sardinian isolate of tomato yellow leaf curl geminivirus with its whitefly vector Bemisia tabaci Gen. Eur. J. Plant Pathol. 101:163-170.

9. Cohen, S., and Nitzany, F. E. 1966. Transmission and host range of the tomato yellow leaf curl virus. Phytopathology 56:1127-1131.

10. Costa, H. S., and Brown, J. K. 1991. Variation in biological characteristics and esterase patterns among populations of Bemisia tabaci, and the association of one population with silverleaf symptom induction. Entomol. Exp. Appl. 61:211-219.

11. Czosnek, H., and Laterrot, H. 1997. A worldwide survey of tomato yellow leaf curl viruses. Arch. Virol. 142:1391-1406. 
12. Duffus, J. E. 1995. Whitefly transmitted yellowing viruses of the Cucurbitaceae. Pages 12-16 in: Cucurbitaceae '94. G. E. Lester and J. R. Dunlap, eds. Gateway Printing, Westlaco, TX.

13. Fargette, D., Leslie, M., and Harrison, B. D. 1996. Serological studies on the accumulation and localization of three tomato leaf curl geminiviruses in resistant and susceptible Lycopersicon species and tomato cultivars. Ann. Appl. Biol. 128:317-328.

14. Gawel, N. J., and Bartlett, A. C. 1993. Characterization of differences between whiteflies using RAPD-PCR. Insect Mol. Biol. 2:33-38.

15. Gibbs, A. J., and Gower, J. C. 1960. The use of a multiple-transfer method in plant virus transmission studies-Some statistical points arising in the analysis of results. Ann. Appl. Biol. 48:75-83.

16. Guirao, P., Beitia, F., and Cenis, J. L. 1997. Biotype determination of Spanish populations of Bemisia tabaci (Homoptera: Aleyrodidae). Bull. Entomol. Res. 87:587-593.

17. Lin, C. S., Poushinsky, G., and Mauer, M. 1979. An examination of five sampling methods under random and clustered distribution using simulation. Can. J. Plant Sci. 59:121-130.

18. Mansour, A., and Al-Musa, A. 1992. Tomato yellow leaf curl virus: Host range and virus-vector relationships. Plant Pathol. 41:122-125.

19. M.A.P.A. 1997. Anuario de Estadística Agraria. Ministerio de Agricultura, Pesca y Alimentación, Madrid, Spain.

20. Matthews, R. E. F. 1991. Plant Virology, 3rd ed. Academic Press, New York.

21. McGrath, P. F., and Harrison, B. D. 1995. Transmission of tomato yellow leaf curl geminivirus by Bemisia tabaci: Effects of virus isolate and vector biotype. Ann. Appl. Biol. 126:307-316.

22. Mehta, P., Wyman, J. A., Nakhla, M. K., and Maxwell, D. P. 1994.
Transmission of tomato yellow leaf curl geminivirus by Bemisia tabaci (Homoptera: Aleyrodidae). J. Econ. Entomol. 87:1291-1297.

23. Moriones, E., Arnó, J., Accotto, G. P., Noris, E., and Cavallarin, L. 1993. Firs report of tomato yellow leaf curl virus in Spain. Plant Dis. 77:953.

24. Navas-Castillo, J., Sánchez-Campos, S., Díaz, J. A., Sáez-Alonso, E., and Moriones, E. 1997. First report of tomato yellow leaf curl virus-Is in Spain: Coexistence of two different geminiviruses in the same epidemic outbreak. Plant Dis. 81:1461.

25. Navas-Castillo, J., Sánchez-Campos, S., Díaz, J. A., Sáez, E., and Moriones, E. 1999. Tomato yellow leaf curl virus-Is causes a novel disease of common bean and severe epidemics in tomato in Spain. Plant Dis. 83:29-32.

26. Noris, E., Hidalgo, E., Accotto, G. P., and Moriones, E. 1994. High similarity among the tomato yellow leaf curl virus isolates from the West Mediterranean Basin: The nucleotide sequence of an infectious clone from Spain. Arch. Virol. 135:165-170.

27. Padidam, M., Beachy, R. N., and Fauquet, C. M. 1995. Classification and nomenclature of geminiviruses using sequence comparisons. J. Gen. Virol. 76:249-263.

28. Reina, J., Jiménez, J., Bejarano, E. R., Guerra, J. M., Cuadrado, I. M. and García, C. 1994. El Virus del rizado amarillo del tomate (TYLCV). Hortifruticultura V(6):36-40.

29. Salas, J., and Mendoza, O. 1995. Biology of the sweetpotato whitefly (Homoptera:Aleyrodidae) on tomato. Fla. Entomol. 78:154-160.

30. Wool, D., Gerling, D., Bellotti, A. C., and Morales, F. J. 1993. Esterase electrophoretic variation in Bemisia tabaci (Genn.) (Homoptera, Aleyrodidae) among host plants and localities in Israel. J. Appl. Entomol. 115:185-196. 